\title{
Projektowanie i realizowanie się w dialogu podmiotów edukacyjnych
}

Projektowanie, czyli planowanie działań i realizowanie się w dialogu podmiotów edukacyjnych, a więc nauczyciela i ucznia, wychowawcy i wychowanka, rodzica i dziecka odbywa się w paradygmacie „współistnienia", który zakłada możliwość wzajemnego rozwoju. Niezbędne jest jednak spełnienie następujących warunków, o których pisał Kazimierz Obuchowski snując rozważania nad analogiami między systemami funkcjonalnymi, takimi jak instytucja społeczna i osobowość człowieka. W kontekście projektowania i realizowania się w dialogu podmiotów edukacyjnych istotne jest ${ }^{1}$ :

- wdrażanie do dysponowania wiedzą o sobie,

- wytyczanie w oparciu o wiedzę zadań dostosowanych indywidualnie do potrzeb i możliwości,

- dobór odpowiednich metod, także nowoczesnych, uwzględniając zmiany zachodzące $\mathrm{w}$ systemach mikro- i makrospołecznych.

Można powiedzieć o autonomicznym generowaniu osobistego modelu świata, projektowaniu i realizowaniu twórczego rozwoju.

$1 \quad$ K. Obuchowski, Rewolucja podmiotów i nowy indywidualizm, [w]: J. Kozielecki (red.), Humanistyka przełomu wieków, Wydawnictwo Akademickie Żak, Warszawa 1999, s. 131-149. 
To jednak na wychowawcy spoczywa trud towarzyszenia w rozwoju wychowanka. Wychowanie jak wskazuje M. Łobocki powinno być świadome. Do warunków świadomego wychowania autor zalicza²:

- podmiotowe traktowanie dzieci i młodzieży,

- demokratyczny styl kierowania wychowawczego,

- pracę nad sobą wychowawców i nauczycieli,

- poznawanie dzieci i młodzieży,

- unowocześnienie kształcenia pedagogicznego.

Zwracam uwagę na potrzebę projektowania i realizowania się w dialogu, konieczność wypracowania zasad, metod inspirujących do pracy nad sobą przy jednoczesnym pobudzaniu do refleksji nad własnym życiem, w toku budowania więzi z innymi. Celem jest wzajemne motywowanie się podmiotów edukacyjnych do uzyskania wewnętrznej samodzielności przy jednoczesnym kształtowaniu poczucia odpowiedzialności za siebie i innych. Niezbędna jest tu autodiagnoza, wymagająca zaangażowania, autorefleksji, która pozwala modyfikować zamierzenia rozwojowe. Jak podkreśla E. Sujak zaangażowanie we własny rozwój zgodnie z wyuczoną umiejętnością organizacji pracy, nauki przybiera postać tworzenia planu własnego ,ja” i podejmowania próby systematycznego realizowania tego planu, który często wymaga jednak przewartościowania. Następuje zmiana punktu widzenia, akceptacja dotychczas pomijanego w sobie samym, a jeszcze częściej zmiana kierunku dążenia czy rezygnacja ${ }^{3}$. By zmiana kierunku rozwojowego była budująca pomocna jest autodiagnoza.

Tak jak w każdym holistycznym postępowaniu diagnostycznym, tak i w autodiagnozie najczęściej rozpoczynamy od przyporządkowania występujących cech do określonego typu (autodiagnoza typologiczna), następnie poszukujemy genezy takiego, a nie innego przyporządkowania, ukazania przyczyn (autodiagnoza genetyczna). W dalszej kolejności wyjaśniamy znaczenie i wartość danego stanu, jego istotę w kontekście całościowego, holistycznego funkcjonowania w różnych wymiarach ludzkiego życia (autodiagnoza funkcjonalna). W efekcie projektujemy, wskazujemy perspektywy i możliwe rozwiązania

2 M. Łobocki, Teoria wychowania w zarysie, Oficyna Wydawnicza „Impuls”, Kraków 2008.

3 E. Sujak, Rozważania o ludzkim rozwoju, Wydawnictwo Guadium, Lublin 2006, s. $14-15$. 
profilaktyczne lub terapeutyczne, w zależności od wcześniejszych autodiagnoz (autodiagnoza prognostyczna).

Autodiagnozę należy traktować jako tworzenie nowego rodzaju wiedzy w kontekście odtwórczych i twórczych doświadczeń, obserwacji uczestniczącej, intuicji, rozumowania, kształtowania umiejętności negocjacyjnych ukierunkowanych na dialog jako imperatyw zrównoważonego rozwoju. Autodiagnozowanie wydaje się być wpisane w rozwój człowieka jako refleksja dotycząca odpowiedzi na pytania - kim jestem, dlaczego tym, jak i dlaczego się staję kimś, kim warto być i dlaczego. Jerzy Nikitorowicz uważa, że diagnozowanie siebie jest szczególnie istotne w kontekście pełnionych ról zawodowych, m.in. lekarza, pedagoga, ról rodzinnych i środowiskowych kształtujących więzi i poczucie wspólnoty. Pozwala na określanie celów, którym może podmiot sprostać, z których może się rozliczyć, osiągnąć satysfakcję, zauważyć efekty, dokonać refleksji nad wartościami i zasadami, nad dotychczasowymi działaniami w celu określenia wniosków do dalszych działań. Stąd też autor wiąże autodiagnozę z procesem ustawicznie kształtującej się tożsamości współczesnego człowieka ${ }^{4}$.

Urszula Ostrowska zwróciła uwagę, że spotkanie z samym sobą, czyli wgląd w samego siebie, jest nie mniej znaczący od spotkania interpersonalnego, spotkania z innym człowiekiem. Podkreśla, odwołując się do bogatej literatury przedmiotu, wartość wewnętrznego dialogu, dialogu jako myślenia, namysłu w kontekście wartości, które w procesie moralnego i estetycznego osądzania gdzieś znikają. Wskazuje, że „wewnętrzny dialog nie zawsze zdaje się być należycie uświadamiany i doceniany zwłaszcza w sensie przewartościowania idei myślenia jako monologu, na rzecz kierunku myślenia dialogicznego" ${ }^{\text {. }}$

Mając na uwadze proces kształtowania się tożsamości, każdy z nas, pełniących np. rolę nauczyciela, powinien dokonać autodiagnozy chociażby w kontekście samoregulacyjnej funkcji tożsamości, która polega na zdolności jednostki do podporządkowania działań ustalonym celom, na odpowiedzialności za ich realizację, na umiejętności

$4 \quad$ J. Nikitorowicz, Diagnoza i autodiagnoza w kontekście złożonego procesu kształtowania się tożsamości, [w:] W. Ambrozik, A. Kieszkowska, K. Sawicki (red.), Współczesne dylematy resocjalizacyjne. W stronę twórczej resocjalizacji, Oficyna Wydawnicza „Impuls", Kraków 2018, s. 81-92.

5 U. Ostrowska, Dialog w pedagogicznym badaniu jakościowym, Oficyna Wydawnicza „Impuls”, Kraków 2000, s. 29-30. 
kontrolowania emocji, impulsów, na wytrwałości w dążeniu do realizacji przyjętych zobowiązań, jak też na przejawianiu twórczości i inicjatywy.

Wartościowym poznawczo i metodycznie przykładem analizy typologicznej, z której można skorzystać jest typologia nauczycieli przedstawiona przez Stanisława Dobrowolskiego?. Mamy możliwość usytuowania siebie w kontekście tej typologii. Autor wyszedł z założenia, że podstawowym narzędziem pracy nauczycieli jest ich intelekt, stąd najistotniejsze jest poznanie umysłowości (intelektu) nauczycieli. Powyższe kryterium (współczynnik różnicowania) pozwoliło na wyróżnienie nauczycieli wybitnych, dobrych, niezupełnie odpowiednich i nieodpowiednich. Spośród wybitnych i dobrych zostały wyróżnione umysły rozumowe, intuicyjne, organizacyjne, systematyczne, wyobrażeniowe, ekspresyjne. Ukazując walory typologii zwracam uwagę na te cechy, które są wiodące w pracy nauczyciela i nadają barwę jego pracy.

Typ rozumowy dąży do tego, by jak najwięcej wiedzieć (erudyci), gruntownie poznać i zrozumieć (myśliciele). Erudyci posługują się głównie pamięcią, myśliciele zaś skupioną uwagą. W tej grupie wyróżniono także umysły refleksyjne, których specjalne zainteresowania skierowane były na życie wewnętrzne, na proces przeżyć i myślenia (dyskusja z samym sobą). Autor zwrócił uwagę, że nauczyciele typu rozumowego wykazują małe zainteresowanie problemami wychowawczymi, problemami życia społecznego, praktycznego, pracami administracyjnymi. Bliższy jest im materiał nauczania (lekcje prowadzone są w sposób jasny, przejrzysty, logiczny) niż uczeń (krytyczni, wymagają poprawności, mało tolerancyjni, zainteresowani uczniami wyróżniającymi się).

Typ intuicyjny interesuje się bardziej różnymi zjawiskami i faktami niż pojęciami, bardziej rzeczywistością niż abstrakcją. Posiada

$6 \quad$ Szerzej: E. Gurba, Budowanie własnej tożsamości warunkiem godnej postawy wobec siebie i otaczającego świata, [w:] B. Zimoń-Dubowik, M. Gamian-Wilk (red.), Oblicza tożsamości: perspektywa interdyscyplinarna, Wydawnictwo Naukowe Dolnośląskiej Szkoły Wyższej, Wrocław 2008, s. 89-99.

7 S. Dobrowolski, Struktury umysłów nauczycieli, PZWS, Warszawa 1980; Por. J. Nikitorowicz, Diagnostyka $i$ metodyka $w$ dialogu wspierającym ludzka egzystencje, [w:] J. Nikitorowicz, K. Sawicki, T. Bajkowski (red.), Współczesne dylematy diagnostyczne i metodyczne w opiece i wychowaniu, Wydawnictwo Wszechnicy Mazurskiej, Olecko 2003, s. 17-19. 
wyczucie procesu opiekuńczo-wychowawczego, łatwość nawiązywania kontaktów z uczniami, ściśle związany jest z życiem szkoły i środowiska. Jest wychowawcą z zamiłowania. Umysły tego typu cenią w pierwszej kolejności mądrość życiową, natomiast nie pociąga ich dziedzina rozważań teoretycznych. Posiadają zdolność wyczuwania psychiki uczniów, potrzeb i zainteresowań, co przejawia się w doborze trafnych środków dydaktycznych oraz w zachowaniach tolerancyjnych.

Typ organizacyjny charakteryzuje całościowe ujmowanie problemów edukacyjnych (zespołu uczniowskiego, lekcji, materiału nauczania i innych elementów). Nauczyciele tego typu przywiązują szczególne znaczenie do konstrukcji lekcji, jej elementów (praca domowa, podanie nowego materiału, utrwalanie, kontrola, ocena i inne). Umiejętności organizacyjne przejawiają się w ujmowaniu tematyki lekcji w formie zagadnień, w prowadzeniu i wywoływaniu dyskusji. Ten nauczyciel nie pozwala na odchodzenie od tematu.

Typ systematyczny dąży do upraszczania wykonywanych czynności, posiłkowania się prostymi środkami, schematycznymi zestawami, podziałami. Powyższym umysłom odpowiadają elementy proste i jednorodne, gdyż mają słabsze poczucie związków zachodzących pomiędzy procesem nauczania i wychowania. Generalnie lubią utarte szlaki i szablony, charakteryzuje je skłonność do porządkowania, naśladownictwa, posługiwania się tymi samymi metodami i środkami dydaktycznymi, stąd stronią od indywidualistów zarówno w procesie opiekuńczo-wychowawczym, jak i w dydaktycznym.

Typ wyobraźniowy charakteryzuje skłonność do intensywnych przeżyć i operowania obrazami, czemu najczęściej towarzyszy umiejętność wywoływania przeżyć u innych osób, odczuwania potrzeby nowych wrażeń, zachowań twórczych, z jednoczesną niechęcią do naśladownictwa i powtarzania. $Z$ jednej strony charakterystyczna dla tego typu jest plastyczność myśli, żywy, bezpośredni kontakt z uczniem, ożywianie procesu dydaktycznego, ale z drugiej, brak ciągłości i konsekwencji, zbytnia aktywność i niecierpliwość, spontaniczność, co skutkuje pewną chaotycznością i subiektywizmem. Nauczyciele ci starają się proponować uczniom rzeczy nowe, interesujące, a nawet to, co jest banalne próbują zaprezentować ciekawie, unikając szablonowego podejścia do tematu. Mniejszą wagę zwracają na utrwalanie materiału, kontrolę, egzekwowanie, ocenianie, jak też na działalność wychowawczą, 
wpływając głównie na rozwój uczuciowości wychowanków, kształtując przeżywanie wartości kultury.

Typ ekspresyjny w sposób wyrazisty oddaje stany psychiczne (pewne uczucia, pragnienia, myśli) z intencją przekazywania ich innym. Najważniejszym środkiem ekspresji nauczyciela jest głos wraz z charakterystyczną dynamiką, intonacją, akcentowaniem. W przypadku tego typu nie ma miejsca na prostotę, natomiast częste jest wysuwanie siebie na pierwszy plan z silną potrzebą uznania, a nawet adoracji. Nauczyciele tego typu operują bardziej formą niż treścią, stąd może mieć miejsce dominowanie formy nad treścią, pozorów nad istotnymi wartościami.

Nauczyciel, wychowawca, rodzic zobligowany jest do planowania, tworzenia projektu swego działania. Wychowawstwo jest czymś więcej niż zawodem - powiedział Janusz Korczak. Zatem tak ważna rola zobowiązuje do działań przemyślanych, nie zaś chaotycznych, w które wpisane jest znacznie więcej błędów wychowawczych. Oddziaływania wychowawcze muszą być prawdziwe, autentyczne. Tylko wtedy możliwe jest, by nauczyciel/wychowawca sam się doskonalił i pomagał rozwijać uczniom/wychowankom ich kompetencje, które zostaną docenione w przyszłości i staną się źródłem satysfakcji dla nich samych.

Zespół naukowców z IFTF-Institute for the Future Uniwersytetu w Phoenix przygotował listę niezbędnych w 2020 roku kompetencji. Wśród nich znalazły się:

1) Sense-making: zdolność do odkrywania, ale i nadawania głębszego sensu temu, co chcemy wyrazić;

2) Social intelligence: inteligencja społeczna, czyli zdolność do komunikowania się w prosty i bezpośredni sposób, ale także wchodzenie w relacje międzyludzkie;

3) Novel § Adaptive thinking: myślenie adaptacyjne, biegłość w rozwiązywaniu problemów, wymyślaniu rozwiązań i odpowiedzi wykraczających poza schemat;

4) Cross-cultural competency: kompetencje kros-kulturowe, czyli zdolność do operowania w zróżnicowanym środowisku kulturowym;

5) Computational thinking: zdolność przetwarzania dużej ilości informacji, rozumowania opartego na danych;

8 https://wszystkoconajwazniejsze.pl/ (dostęp: 12.07.2019). 
6) New media literacy: umiejętność korzystania z nowych mediów. To umiejętność publikowania oraz krytycznej oceny i opracowania treści publikowanych w nowych mediach, a także wykorzystania ich w skutecznej komunikacji;

7) Transdisciplinarity: interdyscyplinarność rozumiana jako umiejętność czytania i rozumienia pojęć w wielu dyscyplinach;

8) Design mindset: myślenie projektowe czy zdolność do prezentowania i rozwijania sposobów pracy dla osiągnięcia pożądanych wyników;

9) Cognitive load management: zdolność do zmaksymalizowania funkcjonowania poznawczego i przyswojenia wielu bodźców przy użyciu różnych narzędzi i technik;

10) Virtual collaboration: zdolność do współpracy wirtualnej w sposób wydajny, zaangażowany i wykazujący obecność w pracy wirtualnego zespołu.

Proces rozwijania wyżej wymienionych cech, zdolności, umiejętności i kompetencji u wychowanka, wymaga dużego zaangażowania wychowawcy w proces samodoskonalenia i ustawicznego kształcenia. Kształtowanie wymienionych kompetencji wymaga determinantów, odpowiednich warunków.

Za determinanty autentycznych i znaczących oddziaływań wychowawczych H. Rylke i G. Klimowicz uznały: zapewnienie klimatu bezpieczeństwa psychologicznego i zaufania, otwartą komunikację, uważne słuchanie, powstrzymywanie się od wyrażania ocen szczególnie krytycznych, używanie informacji zwrotnych, swobodę w poszukiwaniu informacji i rozwiązań ${ }^{9}$.

Istotny jest tu dobór metod i technik, które zostaną zastosowane w procesie zbierania danych o jednostce, grupie, instytucji, określonym zjawisku. Za najważniejszą metodę prowadzącą do poznania wychowanka uznawał Janusz Korczak obserwację, a Helena Radlińska wywiad w miejscu zamieszkania.

W kontekście dialogu będzie to dialog wewnętrzny, który prowadzi wychowanek i wychowawca, a który w efekcie sprzyja tworzeniu projektu wychowawczego. Pojęcie to E. Marynowicz-Hetka pojmuje jako obraz antycypowany, który staramy się osiągnąć w następstwie

$9 \quad$ H. Rylke, G. Klimowicz, Szkoła dla ucznia. Jak uczyć życia z ludźmi, WSiP, Warszawa 1982, s. $10-11$. 
przyjętych operacji prowadzących do nowego stanu rzeczywistości, stanu zmodyfikowanego ${ }^{10}$.

Projekt zmian wychowawczych w duchu dialogu pozwala zauważyć potrzeby, usłyszeć oczekiwania, szybko zareagować na problemy. Kontakt dialogiczny sprzyja działaniom autonomicznym, rozbudza kreatywność jednostek. Istotne są warunki i kultura prowadzenia dialogu. Prowadząc dialog pamiętamy o zasadach etyki. Ważne jest, by wyciszyć zbędne emocje i nie przyjmować postawy uprzywilejowanej, a w drugim człowieku zauważać dobro. Przyjąć postawę otwartości w stosunku do drugiego traktując go jako podmiot.

Hanna Rylke i Grażyna Klimowicz podkreślają, że najlepiej, gdy uczeń korzysta z własnego planu rozwojowego, jednak nauczyciel nazywany w psychologii humanistycznej facylitatorem, czyli osobą ułatwiającą komuś uczenie się pomaga zorganizować czas, zestaw odpowiednich źródeł informacji, służy swoim doświadczeniem, wiedzą, ponadto powinien odznaczać się cechami, które można traktować jako rezultat indywidualnej pracy nad sobą, należą do nich: autentyczność, akceptacja i zaufanie do ludzi, rozumienie empatyczne ${ }^{11}$.

W tym kontekście dialog staje się pomostem łączącym wychowanka i wychowawcę. Józef Tischner, twierdził, że pierwszym warunkiem dialogu jest zdolność do „wczuwania się” w punkt widzenia drugiego. Ale nie chodzi tylko o współczucie, lecz o coś jeszcze - o uznanie, że nasz rozmówca ze swego punktu widzenia ma trochę racji ${ }^{12}$.

„Warunkami minimalnymi dla zaistnienia prawdziwego dialogu są: dobra wola stron, wzajemna otwartość, szczerość, wspólnota celów i nadrzędnych wartości. Gdy zabraknie warunków minimalnych, nie warto "dialogować", usprawiedliwione jest wówczas niepodejmowanie dialogu albo odmowa jego prowadzenia"13.

10 E. Marynowicz-Hetka, J. Piekarski, Wokół problemów działania społecznego. Wybór tekstów przykładów projektów działania, Biblioteka Pracownika Socjalnego, Katowice 1998.

11 H. Rylke, G. Klimowicz, Szkoła dla ucznia..., s. 11.

12 Por. J. Tischner, Świat ludzkiej nadziei, Wydawnictwo Znak, Kraków 1992, s. 20.

13 P. Studnicki, Warunki dialogu i jego charakterystyczne cechy, https://opoka.org.pl/ biblioteka/I/IC/petrus2016_dialog_02.html (dostęp: 23.07.2019); więcej: Idem, Dialog jako wartość, Wydawnictwo PETRUS, Wieliczka 2016. 
Autentyczny dialog winien charakteryzować się otwartością, szczerością, życzliwością, cierpliwością, umiejętnością słuchania ${ }^{14}$. Uważne słuchanie pozwala zauważyć drugiego człowieka i skoncentrować się na nim, na jego potrzebach.

Piotr Studnicki przywołuje rozważania papieża Pawła VI w encyklice Ecclesiam suam i wymienia jeszcze cztery inne cechy autentycznego dialogu: jasność wypowiedzi, łagodność, zaufanie, wychowawczą roztropność. Przez jasność wypowiedzi należy rozumieć: prostotę posługiwanie się zrozumiałym językiem, dostosowanym do poziomu słuchacza oraz przejrzystość - uporządkowane wypowiadanie słów i zwięzłość, tak by słuchający mógł w pełni zrozumieć to, co się mówi ${ }^{15}$.

Wychowawcy, który zna wychowanka, jego język, dostrzega potrzeby, łatwiej jest zrealizować projekt wychowawczy, rozwojowy. Wspólne zrozumienie i porozumienie umożliwia realizowanie się podmiotów edukacyjnych.

W tym miejscu chciałabym wskazać, jak planowanie działań utrzymanych w kontakcie dialogicznym pomogło rozwiązać problem dyskryminacji koleżeńskiej z uwagi na różnice kulturowe. To przykład dialogu międzykulturowego.

W grupie wychowanków z rodzin dysfunkcyjnych, z którymi na co dzień pracuję w świetlicy specjalistycznej - jednej z dwóch funkcjonujących przy Dziennym Domu Pomocy Społecznej w Białymstoku doszło do odtrącenia kolegi ze strony rówieśników. Jeden z wychowanków miał romskie pochodzenie. Koledzy przezywali go, stereotypowo wyobrażając sobie Roma. Chłopiec czuł się w obliczu takich okoliczności źle, zaczął nawet unikać zajęć w świetlicy. Z uwagi na fakt, że wychowankowie świetlicy uczęszczali do tej samej szkoły, do wychowawców świetlicy dochodziły informacje od kadry nauczycielskiej, że na terenie szkoły wspomniany uczeń również jest szykanowany.

W obliczu tego problemu zauważono wzmożoną potrzebę podjęcia działań wychowawczych, poprzedzonych procesem diagnostycznym. Podstawą do rozpoznania problemu i podjęcia działań pomocowych był dialog.

Dialog odbywał się wielotorowo, z wychowankiem pochodzenia romskiego oraz wychowankami dokuczającymi mu, a także pozostałymi

14 Ibidem.

15 Ibidem. Por. Papież Paweł VI, Encyklika Ecclesiam suam, ES 81. 
dziećmi ze świetlicy. Rozmowy dotyczyły takich kwestii jak: powód szykanowania, emocje, odczucia, potrzeby obu stron sporu, znajomość Innego, a jak się w efekcie okazało brak wiedzy na temat kultury romskiej, możliwości zmian tj. działań podjętych, zmierzających do poprawy relacji między wychowankami.

Pomocna okazała się tu metoda wspólnej sprawy oraz warsztaty międzykulturowe z bajką międzykulturową z serii Przygody Innego. Bajki w edukacji międzykulturowej oraz Przygody Innego. Bajki międzykulturowe na rzecz integracji dzieci cudzoziemskich ${ }^{16}$, a także warsztaty $Z$ legendą $i$ baśnią regionu Podlasia, w których wzięli udział wychowankowie wspomnianej świetlicy ${ }^{17}$.

Każda bajka z cyklu Przygody Innego przybliżała uczestnikom różnorodność, inność i pozwalała ją zrozumieć, odkryć jej walory. Kolejne bajki uwrażliwiały na odmienność fizyczną, uzmysławiały, że różnice biologiczne, ekonomiczne nie powinny budować barier między ludźmi, że zaburzenia rozwojowe nie stanowią blokady w przyjaźni. Bajki uwrażliwiały na potrzeby ludzi starszych, niepełnosprawnych. Bajki z serii Przygody Innego ukazywały problemy międzykulturowe, m.in. sytuację czeczeńskiego chłopca, czy losy Armana, chłopca z Armenii. Uczestnik zajęć uzmysławiał sobie, jak ważna w życiu każdego człowieka jest rodzina i symbole, przedmioty, które kojarzymy z naszymi bliskimi - tu pomocna była historia chłopca z Turcji. Wychowanek mógł wreszcie zrozumieć, jakie mogą być powody wyjazdu z ukochanej ojczyzny - np. Białorusi.

Szczególnie cenna w obliczu problemu wychowawczego zaistniałego w grupie okazała się bajka ukazująca życie Romów. Młody czytelnik miał szansę przekonać się, że Romowie mogą żyć w taborze, ale też mogą być sąsiadami zamieszkującymi w bloku obok. Wyróżniają się pięknymi strojami, są niezwykle muzykalni. Starsi Romowie noszą tradycyjne stroje, ale młodsi ubierają się bardziej po europejsku i warto nauczyć się, tak jak Basia i jej brat Paweł z bajki międzykulturowej,

16 A. Młynarczuk-Sokołowska, K. Potoniec, K. Szostak-Król, Przygody Innego. Bajki w edukacji międzykulturowej, Fundacja Edukacji i Twórczości, Fundacja Uniwersytetu w Białymstoku, Białystok 2011; A. Młynarczuk-Sokołowska, K. Potoniec, K. Szostak-Król, Przygody Innego. Bajki międzykulturowe na rzecz integracji dzieci cudzoziemskich, Fundacja Dialog, Białystok 2015.

17 A. Józefowicz, A. Sołbut - warsztaty nt. Zabawy z legendą i baśnią regionu Podlasia prowadzone w okresie IV-VI 2016 na Wydziale Pedagogiki i Psychologii UwB. 
chociaż kilku obcych słów, czy zaśpiewać pieśni w języku romani. Dzieci przekonały się, że to, co nieznane, wydaje się dziwne, obce, ale gdy głębiej poznajemy Innego, staje się nam bliższy, wyzwala naszą ciekawość poznawczą, także językową, natomiast brak znajomości języka kolegi może być powodem barier, które łatwo pokonać, gdy posiądziemy umiejętności lingwistyczne ${ }^{18}$.

W budowaniu dialogu międzykulturowego, mając na uwadze realizowanie się podmiotów edukacyjnych, pomocna jest znajomość i prezentacja Innemu swojego regionu. Dlatego $\mathrm{w}$ pokonywaniu konfliktu pomiędzy wychowankami świetlicy DDPS w Białymstoku a romskim kolegą pomocne były też warsztaty „Z legendą i baśnią regionu Podlasia".

Dzieci ze świetlic Dziennego Domu Pomocy Społecznej w Białymstoku dowiedziały się m.in. jak w Bielsku gęsi kuto, rozpoznawały jak ptaki śpiewają, poznawały potrawy przygotowane z ziemniaków, odkrywały magiczne miejsca naszego regionu, doceniając walory okolicznej przyrody.

W pokonaniu konfliktu między rówieśnikami pomocna była ponadto metoda wspólnej sprawy, która obok mediacji, konferencji sprawiedliwości naprawczej, metody „Bez Obwiniania (No Blame)” wpisuje się w nurt sprawiedliwości naprawczej.

Zastosowanie idei i praktyk sprawiedliwości naprawczej jest szczególnie ważne i potrzebne w procesie wychowawczym wobec dzieci i młodzieży, ponieważ uczy odpowiedzialności za swoje zachowania. W rozumieniu sprawiedliwości naprawczej reakcja na łamanie norm i zasad szkolnych nie ma być odwetem, ale procesem, w którym sprawca bierze odpowiedzialność za to, co zrobił, dążąc do pojednania i rzeczywistego wyrównania szkody, na sposób ustalony przez wszystkie osoby poszkodowane: ofiarę i społeczność szkolną. Chodzi nade wszystko o naprawienie szkody, które sprawca wyrządził ofierze i społeczności, ale co szczególnie ciekawe - także samemu sobie. Przewodnią myślą jest więc tutaj nie tylko kompensacja szkody wyrządzonej pokrzywdzonemu, ale naprawienie pokoju i ładu w społeczności, odbudowanie zniszczonych relacji obejmujących szeroką płaszczyznę ofiara - sprawca - społeczność. Istotą programów

18 Więcej w: A. Józefowicz, A. Sołbut, Znaczenie bajki międzykulturowej w rozwoju dzieci w młodszym wieku szkolnym, „Ars Inter Culturas” 2018, nr 7, s. 273-286. 
i praktyk sprawiedliwości naprawczej jest zaangażowanie i współpraca wszystkich osób, w których interesie leży rozwiązanie danego problemu ${ }^{19}$.

Metoda Wspólnej Sprawy (The Metod of Shared Concern) została opracowana przez Anatola Pikasa, szwedzkiego psychologa. Jest pomocna w sytuacjach, gdy grupa wychowanków stosuje przemoc wobec jednego lub kilku kolegów. Głównym celem jest poszukiwanie rozwiązania problemu, bez obwiniania, czy natychmiastowego pojednania zwaśnionych stron oraz praktyczne wprowadzenie podstawowych reguł, pozwalających uczestnikom zajęć na przebywanie w tej samej grupie - bez krzywdzenia innych. W grupie świetlicowej metoda wspólnej sprawy przebiegała według następujących kroków:

- Krok 1 - przeprowadzenie rozmowy z ofiarą.

- Krok 2-zorganizowanie grupy wspierającej/6-8 wychowanków, wśród których znajdują się agresorzy, świadkowie, przyjaciele ofiary.

- Krok 3 - spotkanie grupy wspierającej. Sygnalizujemy, że pewien uczeń czuje się źle w świetlicy. Ktoś opowiada o zdarzeniu. Wychowankowie przedstawiają pomysły dotyczące tego - co można zrobić, by poprawić sytuację-plan.

- Krok 4 - działania grupy wspierającej. Realizacja uzgodnionego planu.

- Krok 5 - spotkanie z grupą wspierającą. Prośba dotycząca kontynuowania działalności.

- Krok 6 - drugi tydzień działań grupy wspierającej. Spotkanie z rodzicami ofiary, obserwacja ofiary - jak sobie radzi.

- Krok 7 -spotkanie pozwalające ocenić efekty.

W efekcie metoda wspólnej sprawy zintegrowała grupę wychowanków świetlicy DDPS w Białymstoku. Wszystkie dzieci były zaangażowane w rozwiązanie konfliktu, pojawiła się rola osób wspierających. Wychowankowie sami byli ekspertami w sprawie, a wychowawca był osobą towarzyszącą im w wychodzeniu z problemu. Dialog wolny od obwiniania i wymuszonych natychmiastowych przeprosin, burza mózgów dotycząca pomysłów porozumienia, zasad wedle których będzie

19 E. Czemierowska-Koruba, Sprawiedliwość naprawcza w szkole, www.spojrzinaczej. pl/index.php/artykuy-uytkownikow/104-ewa-czemierowska-koruba-sprawiedliwo-naprawcza-w-szkole (dostęp: 23.07.2019). 
dalej funkcjonować grupa oraz czas, by się lepiej poznać, swoją kulturę pozwoliły pokonać konflikt rówieśniczy. W tym wszystkim niezbędna jest refleksyjność i warsztat pracy wychowawcy, oparty na solidnym fundamencie, zbudowanym z trzech głównych komponentów: wiedzy, doświadczeniu i intuicji.

\title{
Uwagi końcowe
}

Jak podkreśla J. Nikitorowicz istotne jest rozumienie indywidualności i potrzeb dziecka, postawa refleksyjna wobec siebie i otaczającej rzeczywistości, na którą niejednokrotnie wskazywał Korczak: „Bądź sobą - szukaj własnej drogi. Poznaj siebie, zanim zechcesz dzieci poznać. Zdaj sobie sprawę z tego, do czego sam jesteś zdolny, zanim dzieciom poczniesz wykreślać zakres ich praw i obowiązków. Ze wszystkich sam jesteś dzieckiem, które musisz poznać, wychować i wykształcić przede wszystkim" ${ }^{20}$. Poza powyższym podkreślał, że poglądy obcych ludzi muszą się przełamać we własnym, żywym „Ja”, gdyż żadna książka, żaden lekarz nie zastąpią własnej czujnej myśli, własnego uważnego spostrzeżenia. Stąd przeciwstawiał prawdziwego wychowawcę wychowawcy - dozorcy. Obowiązkiem opiekuna-wychowawcy-nauczyciela w obecnych warunkach wydaje się być systematyczne dokonywanie diagnoz i autodiagnoz wobec dynamiki i nieprzewidywalności kształtującej się tożsamości współczesnego człowieka, który zagubił się w wielości ofert kultury masowej. Jest to niezbędne i konieczne, aby znaleźć i nadać wartość doświadczanej i realizowanej kulturze oraz nadać właściwy kierunek własnemu rozwojowi.

\begin{abstract}
The process of designing and implementing didactic and educational activities should be planned, and thus deliberate, and take into account the needs, possibilities, and expectations of individuals along with a determination of the effects of these activities.

Fulfilling educational goals of the teacher and the student, the educator and the pupil, the parent and the child, assumes coexistence and mutual development. The concept of self-diagnosis, understood as a reflection on the answer to the question of who I am and what
\end{abstract}

20 F. Moskal, Wychowawca - opiekun w poglądach wybitnych pedagogów przeszłości, „Problemy Opiekuńczo-Wychowawcze” 1978, nr 10, s. 359. 
direction I want to go in, is inscribed in development. The process of self-diagnosis and holistic diagnosis make it possible for subjects of the didactic and educational process to strive for harmonious development. Dialogical contact and dialogue motivating both the teacher and his/her student to action are necessary in this mutual coexistence and development. Self-diagnosis and dialogical contact are necessary conditions for the process of continuous development of identity. The author refers to the typology of teachers presented by Stanisław Dobrowolski and mentions the teacher's identity and self-diagnosis.

She also gives examples of intercultural dialogue in an intercultural fairy tale, as well as recognizes the advantages of the common cause method in solving peer conflicts.

\section{Bibliografia}

Dobrowolski S., Struktury umysłów nauczycieli, PZWS, Warszawa 1980.

Gurba E., Budowanie własnej tożsamości warunkiem godnej postawy wobec siebie i otaczajacego świata, [w:] B. Zimoń-Dubowik, M. Gamian-Wilk (red.), Oblicza tożsamości: perspektywa interdyscyplinarna, Wydawnictwo Naukowe Dolnośląskiej Szkoły Wyższej, Wrocław 2008.

Józefowicz A., Sołbut A., Znaczenie bajki międzykulturowej w rozwoju dzieci w młodszym wieku szkolnym, „Ars Inter Culturas” 2018, nr 7.

Łobocki M., Teoria wychowania w zarysie, Oficyna Wydawnicza „Impuls", Kraków 2008.

Marynowicz-Hetka E., Piekarski J., Wokół problemów działania społecznego. Wybór tekstów przykładów projektów działania, Biblioteka Pracownika Socjalnego, Katowice 1998.

Moskal F., Wychowawca - opiekun w poglądach wybitnych pedagogów przeszłości, „Problemy Opiekuńczo-Wychowawcze” 1978, nr 10.

Młynarczuk-Sokołowska A., Potoniec K., Szostak-Król K., Przygody Innego. Bajki międzykulturowe na rzecz integracji dzieci cudzoziemskich, Fundacja Dialog, Białystok 2015.

Młynarczuk-Sokołowska A., Potoniec K., Szostak-Król K., Przygody Innego. Bajki w edukacji międzykulturowej, Fundacja Edukacji i Twórczości, Fundacja Uniwersytetu w Białymstoku, Białystok 2011.

Nikitorowicz J., Diagnostyka i metodyka w dialogu wspierającym ludzka egzystencje, [w:] J. Nikitorowicz, K. Sawicki, T. Bajkowski (red.), Współczesne dylematy diagnostyczne i metodyczne w opiece $i$ wychowaniu, Wydawnictwo Wszechnicy Mazurskiej, Olecko 2003.

Nikitorowicz J., Diagnoza i autodiagnoza w kontekście złożonego procesu kształtowania się tożsamości, [w:] W. Ambrozik, A. Kieszkowska, 
K. Sawicki (red.), Współczesne dylematy resocjalizacyjne. W stronę twórczej resocjalizacji, Oficyna Wydawnicza „Impuls”, Kraków 2018.

Obuchowski K., Rewolucja podmiotów i nowy indywidualizm, [w:] J. Kozielecki (red.), Humanistyka przełomu wieków, Wydawnictwo Akademickie Żak, Warszawa 1999.

Ostrowska U., Dialog w pedagogicznym badaniu jakościowym, Oficyna Wydawnicza „Impuls”, Kraków 2000.

Paweł VI (papież), Encyklika Ecclesiam suam, ES 81.

Rylke H., Klimowicz G., Szkoła dla ucznia Jak uczyć życia z ludźmi, WSiP, Warszawa 1982.

Studnicki P., Dialog jako wartość, Wydawnictwo PETRUS, Wieliczka 2016.

Sujak E., Rozważania o ludzkim rozwoju, Wydawnictwo Guadium, Lublin 2006.

Tischner J., Świat ludzkiej nadziei, Wydawnictwo Znak, Kraków 1992.

\section{Netografia}

https://wszystkoconajwazniejsze.pl/ (dostęp: 12.07.2019).

Studnicki P., Warunki dialogu i jego charakterystyczne cechy, https:// opoka.org.pl/biblioteka/I/IC/petrus2016_dialog_02.html (dostęp: 23.07.2019). 